\title{
Rainfall patterns and the contribution of litter in the caatinga dry tropical forest ${ }^{1}$
}

\author{
Padrões de chuva e a contribuição da serapilheira em uma floresta tropical seca \\ caatinga
}

\author{
Eveline Viana Salgado ${ }^{2 *}$, Eunice Maia de Andrade ${ }^{3}$, Joaquín Navarro Hevia ${ }^{4}$, Edson Paula Nunes ${ }^{5}$ Meilla \\ Marielle de Araújo Rodrigues ${ }^{6}$
}

\begin{abstract}
The present study was designed to investigate the dynamics of rainfall patterns on the production and rate of decomposition of litter in the caatinga biome. To this end, a data series which had been recorded over 30 years (1981-2010) was used; the indicators taken into consideration being the irregular rainfall index, humidity index and consecutive wet and dry days. Litter was collected monthly over a period of two years (2009-2010) at 20 different locations, and totalled 480 samples. Samples were taken from all live individuals with a stem diameter of $\geq 0.03 \mathrm{~m}$ and a height of $\geq 1 \mathrm{~m}$ : 562 individuals in 25 recorded species were identified. The annual irregular rainfall index, calculated from the series, was 8.45 , with a maximum precipitation of $1,763.9 \mathrm{~mm}$ (1985) and a minimum of $208.8 \mathrm{~mm}$ (1983). The difference in annual rainfall during 2009/2010 was $787.9 \mathrm{~mm}, 2010$ showing greater temporal variability when compared to 2009. Using the humidity index, these years were classified as very wet and very dry respectively. The total annual rainfall influenced the annual production of litter, with $6034.22 \mathrm{~kg} \mathrm{ha}^{-1}$ and $3311.96 \mathrm{~kg} \mathrm{ha}^{-1}$ for 2009 and 2010 respectively. The temporal distribution of rainfall brings forward leaf senescence. In 2010 eight dry spells were recorded, and those that occurred in May and June particularly caused the leaves to fall earlier by almost 60 days, demonstrating that the distribution of rainfall over time speeds up the aging of leaves.
\end{abstract}

Key words: Rainfall indices. Droughts. Caatinga biome. Decomposition of litter.

RESUMO - O presente estudo foi desenvolvido a fim de investigar a dinâmica do regime pluviométrico na produção e taxa de decomposição da serapilheira do bioma caatinga. Para tanto, empregou-se uma série histórica de 30 anos (1981-2010) e os indicadores considerados foram Índice de irregularidade pluviométrica e Índice de umidade e dias consecutivos úmidos e secos. As coletas de serapilheira foram realizadas mensalmente por um período de 2 anos (2009-2010) em 20 pontos distintos, totalizando 480 amostras. Foram amostrados todos os indivíduos vivos com diâmetro do caule $\geq 0,03 \mathrm{~m}$ e altura $\geq 1 \mathrm{~m}$, sendo identificados 562 indivíduos em 25 espécies registradas. O índice de irregularidade pluviométrica anual, avaliado na série, foi de 8,45, com precipitação máxima de 1.763,9 mm (1985) e mínima de 208,8 mm (1983). A diferença da precipitação anual entre os anos 2009/2010 foi de 787,9 mm e o ano de 2010 apresentou uma maior variabilidade temporal quando comparado com 2009. De acordo com o índice de umidade os mesmo foram enquadrados nas classes muito úmida e muito seca, respectivamente. A precipitação total anual influenciou a produção de serapilheira anual com 6.034,22 kg ha' $\mathrm{e} 3.311,96 \mathrm{~kg} \mathrm{ha}^{-1}$, para os anos de 2009 e 2010, respectivamente. A distribuição temporal das chuvas antecipa a senescência das folhas. Em 2010 foram contabilizados 8 veranicos e principalmente os que ocorreram nos meses de maio e junho anteciparam a queda das folhas, praticamente em 60 dias, expressando que a distribuição temporal das chuvas, antecipa a senescência das folhas.

Palavras-chave: Índices pluviométricos. Veranicos. Levantamento florístico do Bioma Caatinga. Serapilheira-decomposição.

DOI: $10.5935 / 1806-6690.20150009$

*Autor para correspondência

'Recebido para publicação em 02/09/2013; aprovado em 23/01/2015

Parte da Tese de Doutorado do primeiro autor apresentada Programa de Pós Graduação em Engenharia Agrícola, Departamento de Engenharia Agrícola/UFC

2Departamento de Engenharia Agrícola/CCA/UFC, Rua, Eduardo Bezerra 175, Fortaleza-CE, Brasil, 60130 270, eveline_agronomia@hotmail.com

${ }^{3}$ Departamento de Engenharia Agrícola/CCA/UFC, Fortaleza-CE, Brasil, eandrade@ufc.br

${ }^{4}$ Departamento Ingeniería Agrícola y Forestal/UVa/España, jnahev@iaf.uva.es

${ }^{5}$ Departamento de Biologia/CT/UFC, Fortaleza-ce, Brasil, edsonpn@ufc.br

${ }^{6}$ Departamento de Engenharia Agrícola/CCA/UFC, Fortaleza-ce, Brasil, meillamarielle@ hotmail.com 


\section{INTRODUCTION}

The Caatinga biome is the main ecosystem existing in northeastern Brazil, extending throughout the area of semiarid climate (MAIA, 2004). Caatinga is made up of dry and thorny vegetation having xerophytic characteristics. In the vegetation, grasses, shrubs and trees of low or mediumheight (3-7 metres), deciduous with small leaves and deep, thick roots, as well as a large amount of cacti and bromeliads can all be found (MAIA, 2004; SOUTO et al., 2009).

The deposit of organic material in the soil from vegetation, acts directly to protect the soil against erosion, preserve soil fertility, store water, increase the micro-fauna and protect against pests (COSTA et al., 2007). The litter represents material deposited on the ground by the vegetation, and is comprised of leaves, flowers, fruits, branches, the remains of stems and material of animal origin.

The type of vegetation and the environmental conditions are determining factors of the quantity and quality of material that falls to the ground, and determine the heterogeneity and the rate of decomposition of the litter (DESCHEEMAEK et al., 2006; MATA et al., 2011; SAURAMAS et al., 2012; VANDERBILT et al., 2008). The amount of litter-forming material in tropical forests varies between 3.6 and $12.4 \mathrm{~kg} \mathrm{ha}^{-1}$ (ANDRADE et al., 1999).

Both biotic and abiotic factors influence litter production, such as the type of vegetation, altitude, latitude, climatic conditions (BRANDT et al., 2010), topography (ANAYA et al., 2012), deciduousness, sequential stage, water availability and soil characteristics. Depending on the characteristics of each ecosystem, any one particular factor may prevail over the others (NAVARRO HEVIA, 2002; PANDEY et al., 2007; QUIDEAU et al., 2005). For the climatic variables, precipitation and temperature exercise greater influence on the formation of litter (BARLOW et al., 2007; FRASER; HOCKIN, 2013).

In regions whose geological base results in shallow and / or impermeable soils, the formation of biomass by the vegetation is totally dependent on the rainy season, since water storage by the soil is limited, there thus being no water available to plants. Authors like Lopes et al. (2009), Pucheta et al. (2006) and Silva et al. (2011) studying the production of litter in an area of caatinga, found that the depositing of litter presents a peak in production at the start of the dry season, showing a close relationship with rainfall, thereby affirming the deciduous character of this biome, as well as of other tropical ecosystems (BARLOW et al., 2007; SILVA et al., 2011; VANDERBILT et al., 2008).

The main inductive source of rainfall in the Brazilian semiarid region is the ITCZ (Inter-Tropical Convergence Zone), which occurs from January to May, with a maximum in March and April (ANDRADE et al., 2010). The upward movement of air, associated with the ITCZ causes precipitation which is generally intense and of convective origin, and which does not display a well-defined frequency of occurrence, resulting in a pattern of anomalous rainfall with a highly variable spatial and temporal distribution (ALVES et al., 2009; FERREIRA; MELLO, 2005; GUERREIRO et al., 2013). The high spatial and temporal variability of the rainfall increases the risk of seasonal drought in semiarid regions (MUPANGWA et al., 2011).

Faced with the high variability of rainfall in the region and its interrelation with the production of biomass by the caatinga, the aim of this study was to investigate the influence of the dynamics of rainfall patterns on the productivity and rate of decomposition of litter in a tropical dry forest. It was assumed that the total number of consecutive days reduces the period of leaf fall in tropical dry forests, and that the time required for decomposition is determined by the annual rainfall.

\section{MATERIAL AND METHODS}

\section{Area of study}

The study was carried out at the Elias Andrade Private Natural Heritage Reserve of (RPPN), in the town of General Sampaio in Ceará, located in the watershed of the Riacho das Pedras, which has an area of $130 \mathrm{~km}^{2}$ (Figure 1). The watershed is representative of the soil and climate conditions of the Brazilian semiarid region. The climate is classified as BSw'h' with average monthly temperatures always above $18^{\circ} \mathrm{C}$ and rainfall concentrated in the autumn. The average precipitation, evaporation and sunlight in the region is 763,1 mm (FUNDAÇÃO CEARENSE DE METEOROLOGIA E RECURSOS HÍDRICO, 2014). The study took place over a period of 24 months (February, 2009 to January, 2011).

The predominant soils in the study area are Entisols. The local flora is classified as a ligneous, shrub-like caatinga which is hyper-xerophilic with a physiognomy characterized by small to medium size trees, having a height of less than $7 \mathrm{~m}$ (Cereus giganteus (Engel.) Brit et Rose - mandacaru; Cochlospermum vitifolium (Willd.) Spreng .- pacotê; Mimosa caesalpiniifolia Benth. - sabiá).

\section{Rainfall Patterns}

To get to know the effect of the rainfall on litter production, the years were classified as to the degree of humidity, and the consecutive dry days (dry spells) and consecutive days of rainfall (wet days) were quantified. Also, the annual rainfall-irregularity index $\left(I_{I}\right)$ is defined as a ratio 
Figure 1 - Geographical representation of the Riacho das Pedras watershed, Ceará

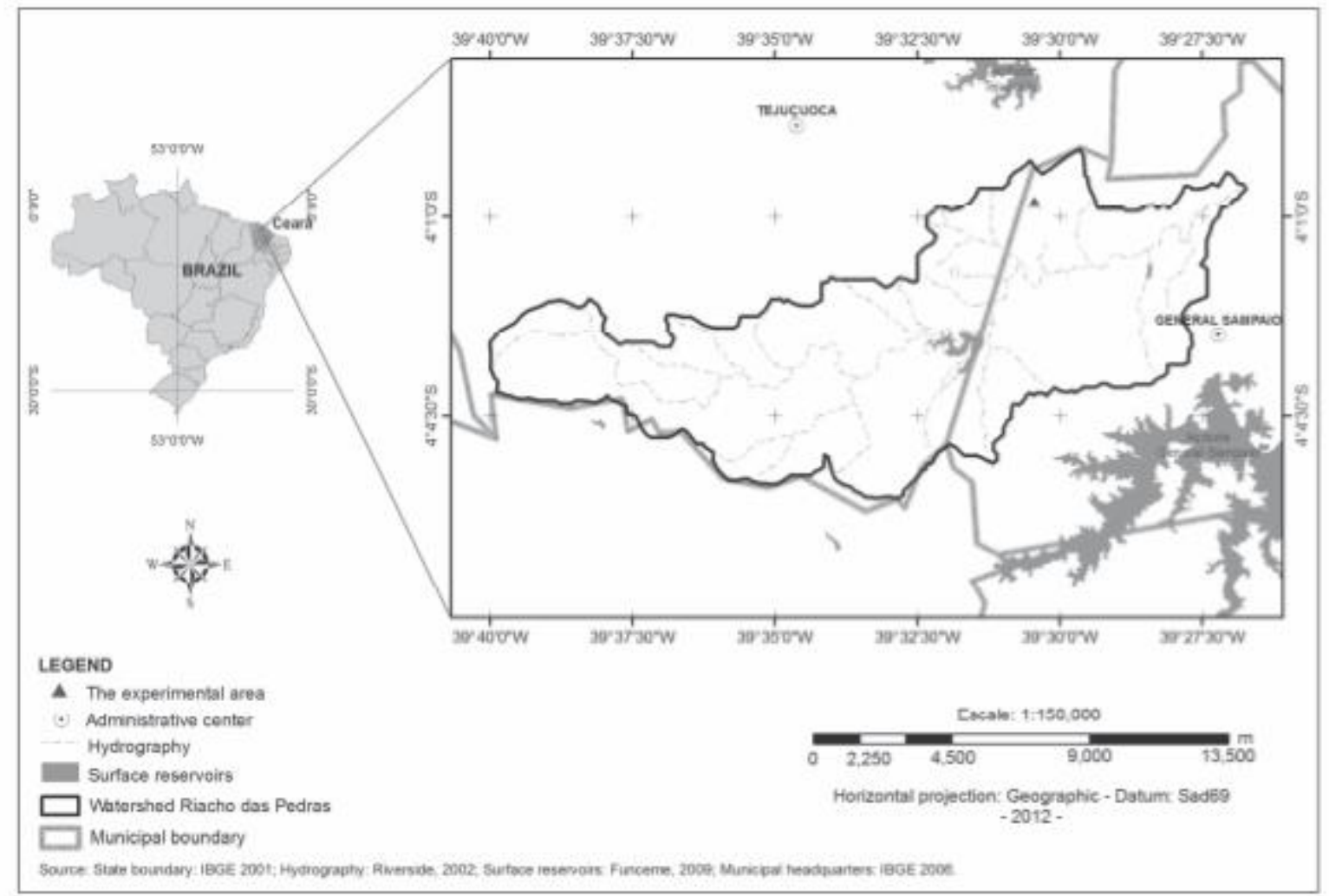

between the precipitation in the year of most rain in the series, and that of the least rain in the series, given by Equation 1.

$I_{I}=\frac{P_{\text {Máx }}}{P_{\text {Min }}}$

Equation (1)

Where: $\mathrm{P}_{\mathrm{Max}}$ is the precipitation of the year with most rain in the series $(\mathrm{mm})$ and $\mathrm{P}_{\text {Min }}$ is the precipitation of the year with the least rain in the series $(\mathrm{mm})$.

Classifying years as to the degree of humidity followed the precept set by the World Meteorological Organization, that there should be a series of 30 consecutive years. The data of total annual rainfall used corresponded to the period 1981 to 2010 , giving a total of 30 years for the amount of rainfall in the Municipality of General Sampaio (FUNDAÇÃO CEARENSE DE METEOROLOGIA E RECURSOS HÍDRICOS, 2014).

In order to classify rainfall as to total annual precipitation, the humidity index (Iu) was determined, having as a basis the studies developed by Aires and Nascimento (2011) and Navarro Hevia (2002). Therefore, the data of total annual rainfall were placed in descending order and divided by class. Rainfall classification was determined from the humidity index $\left(\mathrm{I}_{\mathrm{U}}\right)$, as in Equation 2:

$I_{U}=\frac{P}{\bar{P}}$

Equation (2)
Where: $\mathrm{P}$ is the annual rainfall $(\mathrm{mm})$ and $\bar{P}$ the average rainfall for the series studied $(\mathrm{mm})$.

The classes of $I_{U}$ were defined in line with the highest limit of rainfall found in the new delimitation of the Brazilian semiarid region (BRAZIL, 2013). The rainfall series investigated showed an average precipitation over 30 years equal to $817.55 \mathrm{~mm}$, which was defined as normal with a $50 \%$ probability of occurrence.

After determining probability for a year considered as normal as to the humidity index, a variation of $10 \%$ in the amount of normal rainfall was standardized for normal wet and normal dry years (Table 1). In both wet and dry years, a variation of $30 \%$ relative to the average rainfall was considered, and those values above or below this percentage, became extreme years (very wet and very dry).

In order to investigate the irregularity of daily rainfall in the area under study for 2009 and 2010, box plots or diagrams of extremes and quartiles were constructed and processed using the Statistical Package for Social Sciences software - SPSS 16.0.

To understand the action of rain bursts on the monthly and annual production of litter, the daily rainfall events occurring during the study period (2009 to 2010), 
Table 1 - Classification of years as to humidity index $\left(\mathrm{I}_{\mathrm{U}}\right)$

\begin{tabular}{lc}
\hline \multicolumn{1}{c}{ Year classification } & IU \\
\hline Very wet & IU $>1.3$ \\
Wet & $1.1<\mathrm{IU} \leq 1.3$ \\
Normal wet & $1<\mathrm{IU} \leq 1.1$ \\
Normal & $\mathrm{IU}=1.0$ \\
Normal dry & $0.9 \leq \mathrm{IU}<1$ \\
Dry & $0.7 \leq \mathrm{IU}<0.9$ \\
Very dry & $\mathrm{IU}<0.7$ \\
\hline
\end{tabular}

the relationship between them, and the production and decomposition of litter were all used.

\section{Floristic survey}

The survey of the plant species that produced the litter quantified in this study was performed in 20 plots of $100 \mathrm{~m}^{2}(10 \mathrm{~m} \times 10 \mathrm{~m})$. All individuals with a height of over $1 \mathrm{~m}$ and a stem diameter equal to or greater than $0.03 \mathrm{~m}$ were sampled. Samples were collected every two weeks during the period of February to August 2011. For each collection, botanical material in the reproductive phase was taken, with each plant being triplicated. Subsequently, the samples were dried in a greenhouse with forced circulation at $55{ }^{\circ} \mathrm{C}$ until completely dry (SILVA, 2002). Taxonomic identification was carried out and the exsiccates were processed and duplicates placed in the Prisco Bezerra Herbarium at the Science Center of the Federal University of Ceará (UFC).

\section{Production of litter}

Estimations of monthly and annual litter production produced by the vegetation were determined by distributing throughout the RPPN of 20 collecting boxes $(1 \mathrm{~m} \mathrm{x} 1 \mathrm{~m}$ with a height of $0.15 \mathrm{~m}$ ) and a nylon mesh of $0.001 \mathrm{~m}$ $\mathrm{x} 0.001 \mathrm{~m}$. They were separated from each other by an approximate distance of $30 \mathrm{~m}$. The material deposited in the boxes was collected monthly from February, 2009 to January, 2011. After each collection, the material was broken up into leaves (including leaflets and petioles); reproductive structures (flowers, fruits and seeds); branches (corresponding to all sizes of ligneous parts, including the bark) and miscellaneous (unidentified plant material and material of animal origin).

After sorting, the fractions were placed in paper bags and dried under forced circulation at $65{ }^{\circ} \mathrm{C}$ until reaching a constant weight and then the dry weight (DW) was calculated on precision scales (0.01 g) (SILVA, 2002). The amount of biomass $\left(\mathrm{kg} \mathrm{ha}^{-1} \mathrm{yr}^{-1}\right)$ produced by the caatinga forest of the RPPN was estimated using the average amount of litter contained in the collecting boxes.
To determine the accumulated litter, quarterly samples were taken: in February, May, August and November of 2009 and 2010. For each collection, 20 samples were collected. Each sample consisted of collecting the litter contained in a cast-iron mold, of area equal to $0.25 \mathrm{~m}^{2}(0.5 \mathrm{~m} \times 0.5 \mathrm{~m})$, distributed randomly. This material was then dried, and the DW determined.

The rate of decomposition of the litter was estimated by Equation 3, proposed by Olson (1963), and already used in other similar studies (LOPES et al., 2009; PANDEY et al., 2007; SILVA et al., 2011; SOUTO, 2006; VANDERBILT et al., 2008).

$$
K=\frac{L}{X_{S S}}
$$

Where: $\mathrm{K}$ is the constant of instantaneous decomposition, $\mathrm{L}$ is annual litter production $\left(\mathrm{gm}^{-2}\right)$ and $\mathrm{Xss}$ is the annual average of litter accumulated on the ground $\left(\mathrm{g} \mathrm{m}^{-2}\right)$.

The value of $\mathrm{K}$, or rate of instantaneous decomposition, is the ratio of the mass of litter produced, to the mass of litter accumulated yearly. Once the values of $\mathrm{K}$ for the two years under study had been determined, the average time of renewal was calculated, estimated by $1 / \mathrm{K}$, and the time needed for decomposition of $50 \%\left(\mathrm{t}_{0.5}\right)$ and $95 \%\left(\mathrm{t}_{0.05}\right)$ of the litter, estimated using equations 4 and 5 (SHANKS; OLSON, 1961):

$$
\begin{aligned}
& \mathrm{t}_{0.5}=\ln 2 / \mathrm{K}=0.693 / \mathrm{K} \\
& \mathrm{t}_{0.05}=3 / \mathrm{K}
\end{aligned}
$$

Equation (5)

\section{RESULTS AND DISCUSSION}

\section{Rainfall patterns}

For the recorded series studied (1981 to 2010), the annual rainfall irregularity index was 8.45 , with a maximum precipitation of $1,763.9 \mathrm{~mm}$ (1985) and a minimum of $208.8 \mathrm{~mm}$ (1983), presenting a difference of 1,555.1 mm. According to Lópes e Mitengui (1986), this ratio presents values of $<3$ for temperate regions, it varies between 4 and 5 for continental and oceanic regions, and > 5 in desert climates. Although the climate of the study area is classified as semi-arid, it presented a ratio for desert climates, being higher than that obtained by Navarro Hevia (2002), which was 2.48, with a range of $450 \mathrm{~mm}$ between the maximum and minimum precipitation, in a 40-year series for the region of Palencia, Spain. These facts demonstrate the great interannual variability of rainfall in dry tropical regions (ANAYA et al., 2012; ANDRADE et al., 2010).

The values of $I_{U}$ (Table 2), which classify annual rainfall over the recorded series as to total precipitation, 
demonstrate the high yearly variations. The normal class (Pi equals the average of the series), presented a frequency equal to zero, i.e. in no year during the study period was precipitation equal to the normal average over the 30 years. Researchers like Andrade et al. (1999); Mupangwa et al. (2011) question the period of 30 years as representative of the norm for semiarid regions with high uncertainty of space and time for rainfall events.

The $\mathrm{I}_{\mathrm{U}}$ classifications of regular-dry and normalwet, $\pm 0 \%$ of the normal average, presented a low frequency of occurrence, 0.10 and 0.03 respectively. As for the wet and dry classifications, the frequency was 0.17 and 0.13 , expressing a greater number of years with annual rainfall ranging from \pm 10 to $30 \%$ of the normal average. The highest frequencies were recorded for the extreme classifications, very dry and very wet, totalling $56 \%$ of the years studied, ten were classified as very dry and seven as very wet (Table 2). These results show a greater tendency for extreme events, with high temporal variability. Navarro Hevia (2002) studying a series of 40 years in a semiarid region of Spain, identified a predominance of the normal classification, with rainfall in the range of 400 to $600 \mathrm{~mm}$.

The high temporal variability of rainfall events were confirmed during the two years of the study. For 2009, the total annual precipitation was $1,267.80 \mathrm{~mm}, 55.06 \%$ more than the normal average for the series $(817.6 \mathrm{~mm})$, and in the following year (2010) the annual precipitation was $479.90 \mathrm{~mm}$, expressing a difference of $787.90 \mathrm{~mm}$ between the two. With these values therefore, the two years under investigation fitted into the two extreme classifications, very wet and very dry, and identified a pattern of rainfall of high spatial and temporal uncertainty. In dry environments, annual rainfall may vary from 60 to $150 \%$ (VANDERBILT et al., 2008), and between months, this variation reaches rates of over 500\% (ANDRADE et al., 2010). These changes in the frequency and distribution of rainfall affect the decomposition of litter (ANAYA et al., 2012; PUCHETA et al., 2006).

The temporal variability of the distribution of rainfall events that occurred in those years studied showed distinct trends, expressing high intra- and inter-annual variability
(Figures 2 and 3). These figures plot the daily precipitation as individual points, and may also present atypical or extreme values, represented by asterisks or circles.

In 2009, classified as to the humidity index, as "very wet", there was normal rainfall seen in the region, when precipitation was concentrated in the four months that make up the rainy season (February, March, April and May) (ANDRADE et al., 2010; LOPES et al., 2009). In these months, the figures showed a predominance of rainy days above the average and precipitation representing the "outliers" (values 1.5 times greater than the third quartile) and "extreme points" (values 3 times greater than the third quartile) of 438.4 $\mathrm{mm}$, corresponding to approximately $35 \%$ of the total rainfall that year (2009). In 2010, considered "very dry", as to the humidity index, there was a great predominance of extreme precipitation, i.e. values three times greater than the third quartile. This rainfall all occurred in just 24 days, of the year, representing $46 \%$ of the total precipitation, i.e. $222.4 \mathrm{~mm}$.

Still referring to the above chart (Figure 3), the months which correspond to the rainy season did not present frequent rains, and the median between them remained stable. That is, monthly rainfall was virtually only determined by extreme events, except in April, which recorded the highest monthly rainfall that year of $175.2 \mathrm{~mm}$, with $83.4 \mathrm{~mm}$ corresponding to two extreme events and one outlier.

In the search for a more detailed understanding of the temporal variability of rainfall events, an analysis of the number of dry and wet days recorded in the two years of study was carried out (Figures 4 and 5). In 2009, there were a greater number of rainy days with a total of 96 events between January and July, and an annual precipitation exceeding $150 \%$ that of 2010. In 2010, a total of 54 rainy days were registered, being that 16 of these events occurred in January, when the rainfall season begins. March and April having a total rainfall lower than the monthly historical mean. This fact expresses the uncertainty of the rainfall regime registered by Guerreiro et al. (2013).

For the years studied, 2009 and 2010, the dry days had totals of 269 and 311 respectively, with the presence

Table 2 - Classification by year as to the humidity index $\left(\mathrm{I}_{U}\right)$

\begin{tabular}{lccc}
\hline \multicolumn{1}{c}{ Classification of IU } & IU & Years & Relative Frequency \\
\hline Very wet & $\mathrm{IU}>1.3$ & 7 & 0.23 \\
Wet & $1.1<\mathrm{IU} \leq 1.3$ & 5 & 0.17 \\
Normal wet & $1<\mathrm{IU} \leq 1.1$ & 3 & 0.10 \\
Normal dry & $0.9<\mathrm{IU} \leq 1$ & 1 & 0.03 \\
Dry & $0.7<\mathrm{IU} \leq 0.9$ & 4 & 0.13 \\
Very dry & $\mathrm{IU} \leq 0.7$ & 10 & 0.33 \\
\hline
\end{tabular}


Figure 2 - Temporal analysis, box plot charts of the daily precipitation for 2009

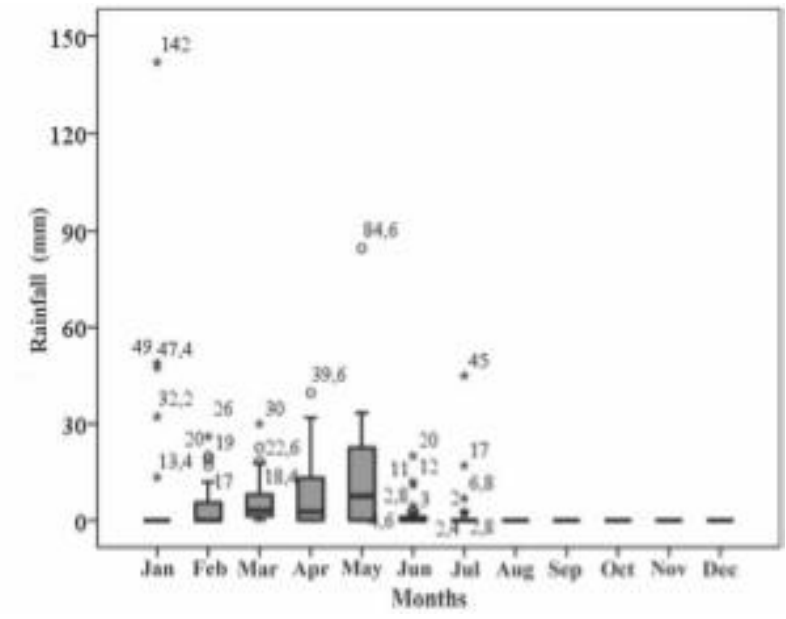

Figure 4 - Total rain bursts per month for 2009 and 2010 and the normal average over 30 years, for the Riacho das Pedras watershed, Ceará

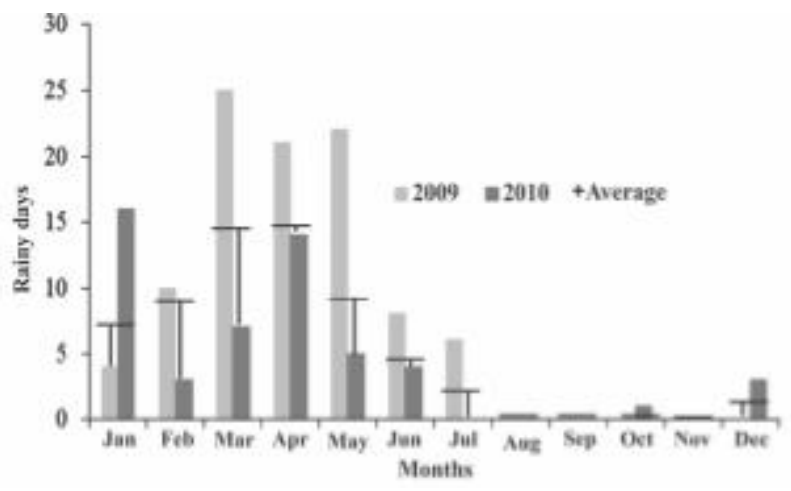

of two dry spells longer than 10 days in 2009 and eight days in 2010. In 2010, these dry spells showed a higher frequency in May and June, however the number of dry days was higher than the average by only three days and one day respectively. In the same year (2010), February and March, being representative of months in the rainy season of the region, had almost only dry days. These days were $37 \%$ and $43 \%$ more than the average for the series, with 26 and 24 dry days respectively. The consistency of the dry spell in the last year (2010) contributed to early leaf fall and the peak monthly production of litter. This confirms the hypothesis that the number of consecutive dry days shortens the period of leaf fall originally calculated for tropical dry forests.

\section{Floristic survey}

In the floristic survey 562 live individuals were identified in 20 plots of $100 \mathrm{~m}^{2}$ each, while Rodal et al.
Figure 3 - Temporal analysis, box plot charts of daily precipitation for 2010

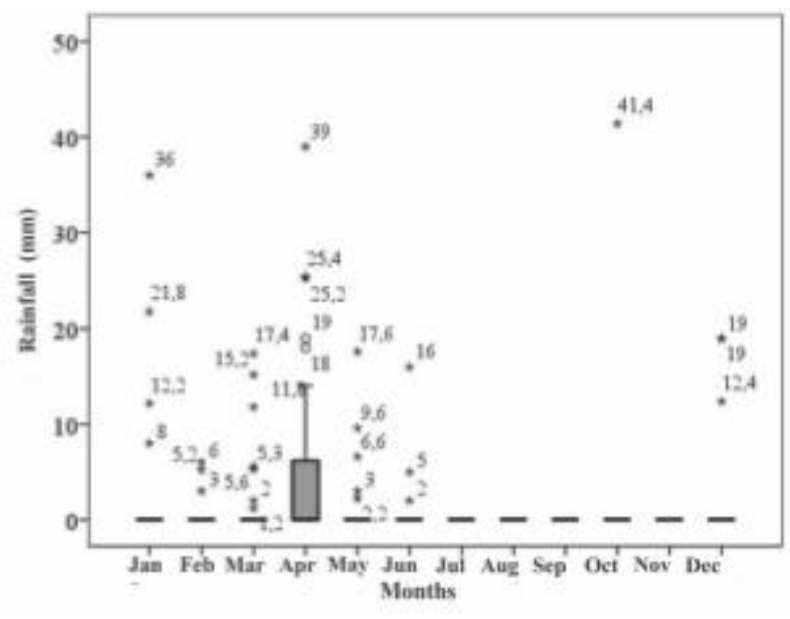

Figure 5 - Total dry days per month for 2009 and 2010 and the normal average over 30 years, for the Riacho das Pedras watershed, Ceará

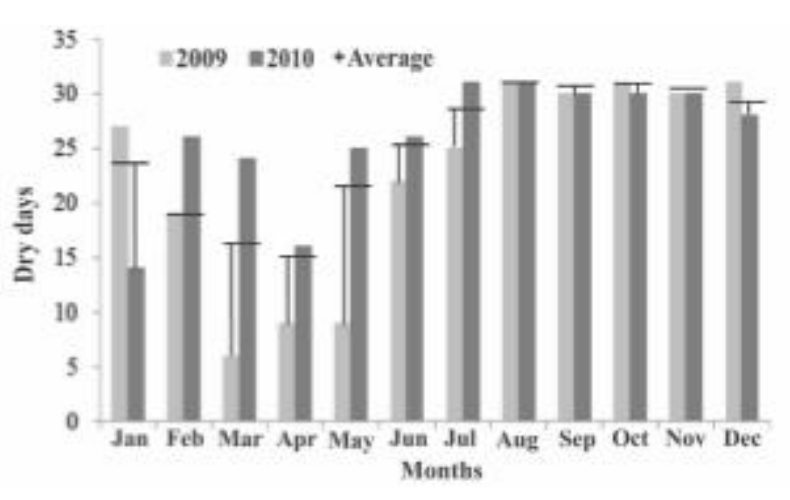

(2008) found 3,140 individuals in 100 plots of $100 \mathrm{~m}^{2}$ each, in an area of 20 years preservation. Although the absolute numbers show different values, the density of individuals in the two areas may be considered as similar, since the area calculated by Rodal et al. (2008) was five times greater than the area of this study, and the vegetation of both studies was the same.

The recorded individuals were grouped into 25 species (Table 3) similar to the quantitative floristic surveys of ligneous plants in areas of caatinga performed by Rodal et al. (2008) and Santana and Souto (2006). These authors identified a total of 28 and 22 species respectively, with different species of caatinga-like plants among those dominant in their surveys.

The most frequent species in surveys of caatinga is Caesalpinia pyramidalis, popularly known as 
Catingueira, it has four different species and its uses include: timber production, folk medicine and forest restoration (MAIA, 2004). In this research Poincianella bracteosa (Tul.) L. P. Queiroz (Catingueira) represented only $9.96 \%$ of identified plants (Table 3 ).

Of the 14 families inventoried, the Fabaceae contributes 9 of the 25 species identified, the Euphorbiaceae 4, and the remaining families only one species, thereby showing that the diversity of this RPPN is concentrated in these two families. This biodiversity is similar to studies carried out by the above-mentioned authors. The predominant species in the RPPN were: Croton blanchetianus Baill. (Marmeleiro preto); Croton anisodontus Müll. Arg. (Marmeleiro branco); Ipomoea subincana (Choisy) Meisn. (Liana) and Combretum leprosum Mart. (Mofumbo), representing 52.14\% of noted species, with a total of 349 plants. The first three species are endemic trees, the third an endemic herbaceous plant and the fourth a non-endemic bush.

It was found that the Euphorbiaceae family usually stands out with the largest number of species in areas of caatinga. This assertion can be seen in this study, where

Table 3 - Species of tree, shrub, herb, and climber, the Elias Andrade Private Natural Heritage Reserve, Ceará, Brazil. NI-number of individuals; RF-Relative Frequency (\%)

\begin{tabular}{|c|c|c|c|}
\hline \multirow{2}{*}{ Family } & Scientific Name & \multirow{2}{*}{ NI } & \multirow{2}{*}{$\mathrm{RF}(\%)$} \\
\hline & Trees & & \\
\hline Apocynaceae & Aspidosperma pyrifolium (Mart) & 14 & 2.49 \\
\hline Anacardiaceae & Myracrodruon urundeuva Fr Allemão & 4 & 0.71 \\
\hline Bignoniaceae & Tabebuia impetiginosa (Mart. Ex DC.) Standl & 4 & 0.71 \\
\hline Bixaceae & Cochlospermum vitifolium (Willd.) Spreng. & 3 & 0.53 \\
\hline Boraginaceae & Auxemma oncocalyx (Allemão) Taub. & 30 & 5.34 \\
\hline Burseraceae & Amburana cearensis (Allemão)A.C.Sm. & 2 & 0.36 \\
\hline Cactaceae & Cereus giganteus (Engel.) Brit et Rose & 8 & 1.42 \\
\hline Combretaceae & Combretum leprosum Mart. & 59 & 10.50 \\
\hline Euphorbiaceae & Croton anisodontus Müll. Arg. & 60 & 10.68 \\
\hline Euphorbiaceae & Croton blanchetianus Baill. & 113 & 20.11 \\
\hline Fabaceae-Caes & Bauhinia cheilantha (Bong.) Steud. & 12 & 2.14 \\
\hline Fabaceae-Caes & Bauhinia pentandra (Bong.) Vogel ex Steud. & 9 & 1.60 \\
\hline Fabaceae-Caes & Bauhinia ungulata $\mathrm{L}$. & 7 & 1.25 \\
\hline Fabaceae-Caes & Caesalpinia ferrea (Mart.) & 2 & 0.36 \\
\hline Fabaceae-Mim & Mimosa caesalpiniifolia Benth. & 47 & 8.36 \\
\hline Fabaceae-Mim & Mimosa tenuiflora (Willd.) Poir. & 32 & 5.69 \\
\hline Fabaceae-Mim & Pityrocarpa moniliformis (Benth.) Luckow \& R.W.Jobson & 8 & 1.42 \\
\hline Fabaceae- Caes & Poincianella bracteosa (Tul.) L.P.Queiroz & 56 & 9.96 \\
\hline Mimosoideae & Chloroleucon dumosum (Benth.) G.P.Lewis & 2 & 0.36 \\
\hline Rutaceae & Fagara sp. & 6 & 1.07 \\
\hline \multicolumn{4}{|c|}{ Shrubs } \\
\hline Euphorbiaceae & Jatropha mollissima (Pohl) Baill. & 3 & 0.53 \\
\hline Euphorbiaceae & Manihot glaziovii Müll. Arg. & 3 & 0.53 \\
\hline Olacaceae & Ximenia americana $\mathrm{L}$. & 4 & 0.71 \\
\hline \multicolumn{4}{|c|}{ Herbacious } \\
\hline Convolvulaceae & Ipomoea subincana (Choisy) Meisn. & 61 & 10.85 \\
\hline \multicolumn{4}{|c|}{ Climber } \\
\hline Fabaceae-Fab & Canavalia brasiliensis Mart. ex Benth. & 13 & 2.31 \\
\hline
\end{tabular}


the species Croton blanchetianus Baill, popularly known as "Marmeleiro Preto", presents the largest number of sampled individuals, $20.11 \%$ of the plants noted or 113 plants. Since this species is present in scrub or arboreal caatinga and in backland and beach areas of carnauba, it can be considered as an indicator of human interference, often being found in places with heavily damaged vegetation. The current classification of the vegetation under study is of a woody shrub-like caatinga, however it cannot be said that the natural state of the vegetation fits this classification, since human action can interfere with this classification (MAIA, 2004; SANTANA; SOUTO, 2006).

\section{Production of litter}

The litter production of a region is a function of the contributing vegetation, precipitation and soil-water availability (SILVA et al., 2011; VANDERBILT et al., 2008). During the study period, the annual litter deposit for 2009 and 2010 was $6,034.22 \mathrm{~kg} \mathrm{ha}^{-1}$ and 3,311.97 $\mathrm{kg} \mathrm{ha}^{-1}$, with a $45 \%$ reduction in production and an average production being estimated as $4,673.10 \mathrm{~kg} \mathrm{ha}^{-1}$. This fact demonstrates the inter-annual variability in litter production and the need for caution in the use of average values. It is noteworthy that the highest deposits occurred in the months of August, 2009 and June, 2010 (Figure 6). These represent the end of the rainy season. There is a delay of three months for maximum productivity relative to the month of greatest precipitation in the wettest year (2009), while in 2010, the leaf fall began in April with a very similar leaf fall in May and June. Bringing forward the higher monthly productivity of litter confirms its interrelationship with the dynamics of the monthly pattern of rainfall.

Precipitation is the climatic factor which interferes directly in the production of litter, however the temporal distribution of the rainfall, especially consecutive dry days (dry spells), speeds up the aging of leaves. As shown in Figure 5, in 2010 eight dry spells of 10 days or more were seen, and mainly those that occurred in May and June brought forward leaf fall that year by almost 60 days.

In the two years (2009 and 2010) the annual litter production presented a difference of $2,722.25 \mathrm{~kg} \mathrm{ha}^{-1} \mathrm{yr}^{-1}$. However, the depth of precipitation in the first year was greater by $787.90 \mathrm{~mm}$ than in the following year. Litter production $\left(6,034.22 \mathrm{~kg} \mathrm{ha}^{-1}\right)$ in 2009 , a year classified as very rainy, resembled that of a subtropical forest in India, with annual precipitation of $1,384 \mathrm{~mm}$ and annual production of $5,477 \mathrm{~kg} \mathrm{ha}^{-1} \mathrm{yr}^{-1}$ (PANDEY et al., 2007). Values of annual litter production recorded for 2010 were close to those found in areas of caatinga by Costa et al. (2007) and Lopes et al. (2009). However these figures are higher than in the studies developed by Souto et al. (2009) and Santana, Souto (2006), who worked

Figure 6 - Monthly variation in litter deposit $\left(\mathrm{kg} \mathrm{ha}^{-1}\right)$ and rainfall $(\mathrm{mm})$ during 2009 and 2010, and normal average rainfall over 30 years

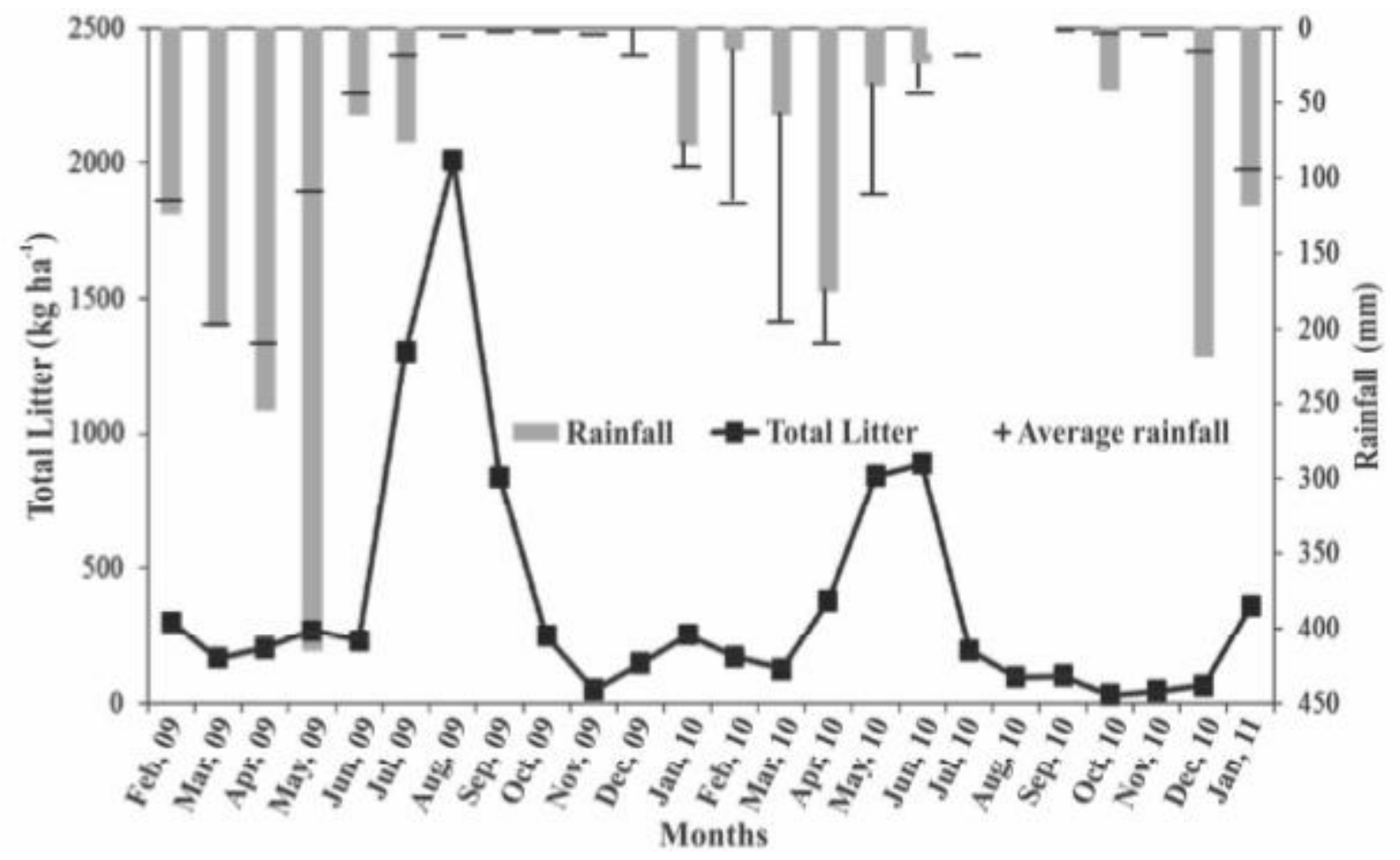


in different regions of the state of Paraíba, Brazil, and obtained average litter deposits of $2,068.55 \mathrm{~kg} \mathrm{ha}^{-1}$ year ${ }^{-1}$ and $1,619.21 \mathrm{~kg} \mathrm{ha}^{-1} \mathrm{yr}^{-1}$ respectively.

For 2009 and 2010 annual litter production was measured $\left(6,034.22 \mathrm{~kg} \mathrm{ha}^{-1}\right.$ and 3,311.96 $\left.\mathrm{kg} \mathrm{ha}^{-1}\right)$ and an annual accumulated average for ground litter calculated of $5,929.80 \mathrm{~kg} \mathrm{ha}^{-1}$ and $6,121.03 \mathrm{~kg} \mathrm{ha}^{-1}$ respectively. From these deposits the decomposition rate or constant $(\mathrm{K})$, the time required for litter renewal $(1 / \mathrm{K})$, and the times for $50 \%\left(\mathrm{t}_{0.5}\right)$ and $95 \%\left(\mathrm{t}_{0.05}\right)$ for decomposition of the litter were all estimated (Table 4).

The constant, $\mathrm{K}$, is considered an estimate of the proportion of decomposition in one year, of the layer of accumulated litter on the ground. The values of $\mathrm{K}$ for both years (Table 4) represent the relationship between the annual deposit of litter and that accumulated on the ground. For 2009 it shows that the total of decomposed litter was similar to the new supply, since the ratio between the two $(\mathrm{K})$ was very close to 1 . In relation to the humidity index, that year was rated as very rainy, with the annual rainfall more than $30 \%$ above the average, reflecting a higher annual production of litter and a shorter time for its decomposition. As for 2010 the decomposition of litter was equivalent to $50 \%$ of what was added $(\mathrm{K}=0.54)$, demonstrating an accumulation of litter on the ground. This fact expresses the relationship existing between rainfall and the decomposition of litter, for in a year with a less moisture (2010), there was less decomposition of the litter, and therefore a lesser supply of nutrients to the soil (QUIDEAU et al., 2005; SAURA-MAS et al., 2012; SOUTO, 2006; VANDERBILT et al.,2008). The correlations between rainfall and the quality of soil cover have a large impact on the processes of decomposition in the central area of New Mexico (VANDERBILT et al., 2008).

The time required for the renewal of litter $(1 / \mathrm{K})$ was 0.98 years (2009) and 1.85 years (2010). In the first year this result was similar to that observed by Souto (2006), with values of 0.91 and 0.70 years, indicating a balanced renewal of litter and availability of nutrients. In the second year, the renewal time is slow and is placed between that of two authors who also worked in this biome, Lopes et al. (2009), who recorded $(1 / \mathrm{K})$ of 1.41 years and Santana, Souto (2005) with 3.03 years.

Table 4 - Constant of decomposition (K), renewal time (1/K) and decomposition times of $50 \%\left(\mathrm{t}_{0.5}\right)$ and $95 \%\left(\mathrm{t}_{0.05}\right)$ for litter in the Elias Andrade RPPN, Ceará, Brazil

\begin{tabular}{lcccc}
\hline \multirow{2}{*}{ Year } & \multirow{2}{*}{$\mathrm{K}$} & \multicolumn{1}{c}{$1 / \mathrm{K}$} & $\mathrm{t}_{0.5}$ & $\mathrm{t}_{0.05}$ \\
\cline { 3 - 5 } & & -------------- & years & ------------- \\
\hline 2009 & 1.02 & 0.98 & 0.68 & 2.95 \\
2010 & 0.54 & 1.85 & 1.28 & 5.56 \\
\hline
\end{tabular}

The time required for decomposition of $50 \%$ $\left(\mathrm{t}_{0.5}\right)$ and $95 \%\left(\mathrm{t}_{0.05}\right)$ were 0.68 years (248 days) and 2.95 years (1,077 days) in 2009 and 1.28 years (467 days) and 5.56 years (2,029 days) in 2010. These figures confirm the values found for $\mathrm{K}$ and the time for the renewal of litter, being shorter in 2009 and longer in 2010. Yet these results are superior to those obtained by Souto (2006), where the time of decomposition in the first year of study were 229.9 days $\left(\mathrm{t}_{0.5}\right)$ and 996.4 days $\left(\mathrm{t}_{0.05}\right)$, and 178.8 days and 770.15 days to decompose $50 \%$ and $95 \%$ in the second period. The time for the decomposition of litter directly depends on biotic and abiotic factors, because the rate of decomposition of organic matter varies with vegetation, climate, soil type, presence of soil organisms and human action, among other things (SILVA et al., 2011). However, studies into the decomposition of litter have a period of evaluation which is considered as being short for arid and semiarid environments, where the factor precipitation is of high variability (VANDERBILT et al., 2008).

\section{CONCLUSIONS}

1. The rainfall irregularity index for the series evaluated (1981 to 2010) was considered high, showing a difference of $1,551.1 \mathrm{~mm}$, between the years of maximum (1985) and minimum (1983) precipitation;

2. The Riacho das Pedras watershed tends to have a greater occurrence of very dry and very wet years, representing $56 \%$ of the relative frequency of the series studied;

3. The large number of plants with reduced stem diameter and height is evidence of a population still in the recovery phase of the original structure, thereby reducing the number of plants identified in the floristic survey;

4. The concentration of rainfall into short periods of time, and the presence of dry spells greater than or equal to 10 days, brought forward the maximum production of litter in 2010 by about 60 days;

5. The maximum monthly production of litter 2009 and 2010, occurred after the reduction in rainfall, thereby maintaining an inverse relationship between the precipitation and the maximum monthly production of litter;

6. The rate of decomposition $(\mathrm{K})$ and renewal time $(1 / \mathrm{K})$ of the litter was considered fast in 2009 and slow in 2010.

\section{ACKNOWLEDGMENTS}

The authors would like to thank the National Council for Scientific and Technological Development 
(CNPq) for the support of this project and the Coordination for the Improvement of Higher Level Personnel (CAPES), for the scholarship of the first author.

\section{REFERÊNCIAS}

AIRES, R.; NASCIMENTO, F. R. Variações pluviométricas em microbacias no vale do Jaguaribe-CE. Revista da Casa da Geografia de Sobral. Sobral, v. 13, n. 1, p. 83-97. 2011.

ANAYA, C. et al. Large Rainfall Pulses Control Litter Decomposition in a Tropical Dry Forest: Evidence from an 8Year Study. Ecosystems, v. 15, n. 4, p. 652-663, 2012.

ALVES, J. M. B. et al. Relationship between ocean climatic variability and rain-fed agriculture in northeast Brazil. Climate Research, v. 38, p. 225-236, 2009.

ANDRADE, A. G. et al. Ciclagem de nutrientes em ecossistemas florestais. Rio de Janeiro: Embrapa Solos, 1999.

ANDRADE, E. M. et al. O semiárido cearense e suas águas. In: ANDRADE, E. M.; PEREIRA, O. J.; DANTAS, F. E. R. O Semiárido e o manejo dos recursos naturais. Fortaleza: Imprensa Universitária, 2010. cap. 3, p. 71-94.

BRANDT, L. A. et al. The role of photodegradation in surface litter decomposition across a grassland ecosystem precipitation gradient. Ecosystems, v. 13, n. 5, p. 765-781, 2010.

BRASIL. Ministério da Integração Nacional. Nova Delimitação do Semiárido Brasileiro. Disponível em: <www.mi.gov.br>. Acesso em: 1 set. 2013.

BARLOW, J. Litter fall and decomposition in primary, secondary and plantation forests in the Brazilian Amazon. Forest Ecology and Management, v. 247, n. 1/3, p. 91-97, 2007.

COSTA, C. C. A. et al. Produção de serapilheira na Caatinga da Floresta Nacional do Açu-RN. Revista Brasileira de Biociências, v. 5, n. 1, p. 246-248, 2007.

DESCHEEMAEKER, K. et al. Litter production and organic matter accumulation in exclosures of the Tigray highlands, Ethiopia. Forest Ecology and Management, v. 233, n. 1, p. 21-35, 2006.

FERREIRA, A. G.; MELlO, N. G. S. Principais sistemas atmosféricos atuantes sobre a região Nordeste do Brasil e a influencia dos oceanos pacíficos e atlântico no clima da região. Revista de Climatologia, v. 1, n. 1, p. 15-28, 2005.

FRASER, L. H.; HOCKIN, A. D. Litter decomposition rates of two grass species along a semi-arid grassland-forest ecocline. Journal of Arid Environments, v. 88, p. 125-129, 2013.

FUNDAÇÃO CEARENSE DE METEOROLOGIA E RECURSOS HÍDRICOS. PCD - Plataforma de coleta de dados. Disponível em: <http://www.funceme.br/produtos/ script/chuvas/Download_de_series_históricas/ download Historicos/postos/49.txt.>. Acesso em: 1 maio 2014.

GUERREIRO, M. J. S. et al. Long-term variation of precipitation indices in Ceará State, Northeast Brazil. International Journal of Climatology, v. 33, n. 14, p. 29292939, 2013.

LÓPES, C.; MINTEGUI, J. A. Hidrología de Superficie. Fundación Conde del Valle de Salazar. E.T.S. de Ingenieros de Montes. Universidad Politécnica de Madrid. Madrid, 1986, 224 p. Tomo 1.

LOPES, J. F. B. et al. Deposição e decomposição de serapilheira em área de Caatinga. Revista Agro@mbiente, v. 3, n. 2, p. 72-79, 2009.

MAIA, G. B. Caatinga: árvores e arbustos e suas utilidades. São Paulo: Leitura e Arte Editora, 2004.

MATA, D. I. et al. Floristic composition and soil characteristic of tropical freshwater forested wetlands of Veracruz on the coastal plain of the Gulf of Mexico. Forest Ecology and Management, v. 262, n. 8, p. 1514-1531, 2011.

MUPANGWA, W. et al. Start, end dry spells of the growing season in semi-arid southern Zimbabwe. Journal of Arid Environments, v. 75, n. 11, p. 1097-1104, 2011.

NAVARRO HEVIA, J. Control de la erosión em desmontes originados por obras de infraestructura viária: aplicación al entorno de Palencia capital. 2002. 316 f. Tesis (Doctorado en Ingenieria de Montes) - Universidad Politécnica de Madrid, 2002.

OLSON, J. S. Energy storage and the balance of producers and decomposers in ecological systems. Ecology, v. 44, n. 2, p. 322-331, 1963.

PANDEY, R. R. et al. Litterfall, litter decomposition and nutrient dynamics in a subtropical natural oak forest and managed plantation in northeastern India. Forest Ecology and Management, v. 240, n. 1/3, p. 96-104, 2007.

PUCHETA, E. et al. Litter decomposition in a sandy Monte desert of western Argentina: Influences of vegetation patches and summer rainfall. Austral Ecology, v. 31, n. 7, p. 808816, 2006.

QUIDEAU, S. A. et al. Leaf litter decomposition in a chaparral ecosystem, Southern California. Soil. Biology \& Biochemistry, v. 37, p. 1988-1998, 2005.

RODAL, M. J. N. et al. Estrutura e vegetação caducifólia espinhosa (Caatinga) de uma área do sertão central de Pernambuco. Hoehnea, v. 35, n. 2, p. 209-217, 2008.

SANTANA, J. A. S.; SOUTO, J. S. Diversidade e estrutura fitossociológica da caatinga na estação ecológica do Seridó-RN. Revista de Biologia e Ciências da Terra, v. 6, n. 2, p. 232-242, 2006.

SAURA-MAS et al. Effects of climate change on leaf litter decomposition across post-fire plant regenerative groups. 
Environmental and Experimental Botany, v. 77, p. 274282, 2012.

SHANKS, R.; OLSON, J. S. First year breakdown of leaf litter in Southern Appalachian Forest. Science, v. 134, n. 3473, p. 194-195, 1961.

SILVA, D. J.; QUEIROZ, C. Análise de alimentos (Métodos químicos e biológicos). Viçosa, MG: Universidade Federal de Viçosa, 2002. 235 p.

SILVA, A. K. L. et al. Litter dynamics and fine root production in Schizolobium parahyba var. amazonicum plantations and regrowth forest in Eastern Amazon. Plant Soil, v. 347, n. 1/2, p. 377-386, 2011.
SOUTO, P. C. Acumulação e decomposição da serapilheira e distribuição de organismos edáficos em área de Caatinga na Paraíba, Brasil. 2006. 146 f. Tese (Doutorado em Agronomia - Solos e Nutrição de Plantas) - Universidade Federal da Paraíba, Brasil. 2006.

SOUTO, P. C. et al. Características químicas da serapilheira depositada em área de caatinga. Revista Caatinga, Mossoró, Brasil, v. 22, n. 1, p. 264-272. 2009.

VANDERBILT, C. S. et al. Aboveground decomposition in arid environments: results of a long-term study in central New Mexico. Journal of Arid Environments, v. 72, n. 5, p. 696-709, 2008. 